\title{
ANALISIS KETERCAPAIAN LABORATORIUM DAN SIMULATOR TEKNIKA DALAM MENUNJANG TEST KOMPREHENSIF PESERTA DIKLAT ATT III DI POLITEKNIK PELAYARAN SURABAYA
}

\author{
Didik Suharso, Hendra Purnomo, Damoyanto Purba \\ Jurusan Teknika, Jurusan Nautika \\ Politeknik Perkapalan Negeri Surabaya \\ email : alif.arso@gmail.com
}

diterima tanggal : 20 Februari 2019, disetujui tanggal : 23 Mei 2019

\begin{abstract}
Abstrak
Dalam sistem penyelenggaraan Ujian Keahlian Pelaut (UKP) bagi peserta Diklat Ahli Teknika Tingkat III (ATT-III), di samping Computer Based Assessment (CBA) test, dilaksanakan praktek komprehensif sesuai STCW 1978 dan amandemennya. Kecukupan sarana laboratorium dan simulator teknika dinilai sangat penting dalam penilaian praktek komprehensif. Salah satu kendala yang dihadapai oleh peserta diklat yaitu penyesuaian tempat ujian praktek komprehensif. Penelitian ini bertujuan untuk mengetahui kelayakan sarana prasarana laboratorim dan simulator teknika dalam mendukung ketercapaian praktek komprehensif pada uji keahlian pelaut bagi peserta Diklat ATT III. Metode yang digunakan dalam penelitian yaitu metode statistik deskiptif. Metode pengumpulan data yang digunakan yaitu observasi dan survei melalui angket kepada ahli, yaitu dosen/akademisi yang telah bersertifikat minimal ATT II. Kompetensi yang harus dimiliki oleh peserta diklat ATT III terdiri dari 4 fungsi. Berdasarkan penilaian ahli menggunakan skala, didapatkan hasil bahwa Fungsi 1 berupa permesinan kapal dengan 8 indikator, memiliki score sebesar 356 dari score maksimal sebesar 384, rata-rata 3,71 dari skala 4 sehingga persentase ketercapaian tes komprehensif sebesar 92,7\%. Pada fungsi 2 berupa listrik elektronika dan sistem kontrol dengan 4 indikator, didapatkan score sebesar 184 dari score maksimal sebesar 192, rata-rata 3,83 dari skala 4 sehingga prosentase ketercapaian tes komprehensif sebesar 95,8\%. Pada fungsi 3 berupa oral \& praktek pada perawatan dan perbaikan permesinan kapal dengan 4 indikator, didapatkan score sebesar 186 dari score maksimal sebesar 192, rata-rata 3,88 dari skala 4 sehingga prosentase ketercapaian tes komprehensif 96,9\%. Untuk fungsi 4 berupa pengendalian pengoperasian kapal dan perlindungan terhadap orang dengan 12 indikator, didapatkan score 576 dari maksimal score sebesar 576, rata-rata 4 dari skala 4, sehingga prosentase ketercapaian tes komprehensif 100\%. Hasil tersebut menunjukkan bahwa fasilitas laboratorium dan simulator teknika sangat layak digunakan dalam menunjang pelaksanaan test komprehensif peserta diklat ATT III di Politeknik Pelayaran Surabaya.
\end{abstract}

Kata kunci : komprehensif, laboratorium dan simulator, peserta diklat

\section{Abstract}

In the system of implementing the Seafarers' Skills Examination for the Technician Level III Expert Training participants (ATT-III), besides the Computer Based Assessment (CBA) test, comprehensive practices were carried out according to the STCW 1978 and its amendments. Adequacy of laboratory facilities and professional simulators is considered very important in a comprehensive practice assessment. One of the obstacles faced by training participants is the adjustment of comprehensive practice exam places. This study aims to determine the sufficiency of laboratory facilities and professional simulators in supporting the achievement of comprehensive practice on seafarers' expertise test for ATT III Training participants. The method used in the research is a descriptive statistical method. The method of data collection used is observation and survey through questionnaires to experts, that is lecturers/academics who have been certified at least ATT II. The competencies that ATT III training participants must have consist of 4 functions. Based on expert judgment using a scale, it was found that Function 1 which include ship machinery with eight indicators, had a score of 356 from a maximum score of 384 , an average of 3.71 on a scale of 4 so that the percentage of 
comprehensive tests was $92.7 \%$. In function two which include electronic electricity and a control system with four indicators, had a score of 184 from a maximum score of 192, an average of 3.83 on a scale of 4 so that the percentage of the comprehensive test is $95.8 \%$. In function three which include oral \& practice on maintenance and repair of ship engines with four indicators, had a score of 186 from a maximum score of 192, an average of 3.88 of a scale of 4 so that the percentage of comprehensive tests is $96.9 \%$. For function four which include vessel operation control and protection of people with 12 indicators, had a score of 576 from a maximum score of 576, an average of 4 on a scale of 4 , so that the percentage of the comprehensive test is $100 \%$. These results indicate that laboratory facilities and professional simulators are very feasible to use in supporting the comprehensive test of ATT III training participants at the Surabaya Shipping Polytechnic.

Keywords: comprehensive, laboratory and simulator, training participants.

\section{PENDAHULUAN}

Penelitian ini dilakukan untuk memastikan kesesuaian/kelayakan laboratorium dan simulator bagi peserta diklat ATT - III dalam ujian test komprehensif dengan materi uji kompetensi UKP sesuai spesifikasi standar minimal kompetensi bagian mesin di Politeknik Pelayaran Surabaya. Dari tes tersebut diharapkan didapatkan hasil yang memuaskan, sehingga tidak ada peserta yang melaksanakan ujian ulang. Pelaksanaan Ujian Keahlian Pelaut (UKP) dengan materi uji kompetensi (test komprehensif) Ahli Teknika Tingkat III, yang diberikan berdasarkan Keputusan Dirjen Perhubungan Laut No.HK.103/4/2/ DJPL-2015 tanggal 12 November 2015, tantang sistem dan prosedur Penyelenggaraan Ujian Keahlian. Dalam hal ini peneliti melihat Materi uji kompetensi (test komprehensif) bagi Ahli Teknika Tingkat III menggunakan metode demonstrasi yang akan dilaksanakan di laboratorium dan simulator teknika. Berdasarkan pengalaman dan kemampuan peserta diklat diharapkan dapat menyelesaikan test komprehensif Ujian Keahlian Pelaut (UKP) dengan fasilitas laboratorium dan simulator teknika yang ada di Politeknik Pelayaran Surabaya. Menindaklanjuti latar belakang tersebut peneliti mengambil judul "Analisis Laboratorium dan Simulator Teknika dalam Menunjang Test Komprehensif Peserta Diklat ATT III di Politeknik Pelayaran Surabaya". Hal tersebut dimaksudkan untuk membuktikan bahwa laboratorium dan simulator teknika Politeknik Pelayaran Surabaya sesuai standar kompetensi STCW 1978 Amandemen 2010 dapat digunakan untuk uji kompetensi (test komprehensif) peserta diklat ATT - III.

Politeknik Pelayaran Pelayaran Surabaya memiliki fasilitas penunjang kegiatan pembelajaran peserta diklat sesuai persyaratan berupa laboratorium dan simulator penunjang kegiatan pembelajaran sesuai mata kuliah pelajaran yang bisa dilakukan sesuai metode untuk uji kompetensi (demonstrating competence) di laboratorium dan simulator sesuai
STCW 2010. Terkait dengan penggunaan sarana simulator dalam upaya peningkatan kompetensi pelaut, Hartanto [1] telah melakukan studi untuk mengetahui utilitas simulator terhadap peningkatan kompetensi navigasi taruna. Laboratorium dan simulator merupakan sarana yang digunakan untuk menggali kemampuan peserta diklat sesuai kompetensi yang telah di pelajari melalui uji kompetensi baik secara tertulis/teori dengan teknik pengamatan/observasi. Sutrisno Hadi dalam Sugiyono [2] mengemukakan bahwa, observasi merupakan suatu proses yang kompleks, suatu proses yang tersusun dari berbagai proses biologis dan psikologis. Berdasarkan Surat Keputusan Direktur Politeknik Pelayaran Surabaya dibidang Jurusan Teknika Mengacu buku referensi STCW [3] Amandemen 2010, IMO Model Course 7.04, IMO Model course [4], simulator dalam Train the Simulator Trainer and Assessor, IMO Model course 6.10 , laboratorium dan simulator digunakan untuk uji kompetensi baik teori maupun praktek komprehensif peserta diklat oleh akademisi/dosen. Oleh karena itu, simulator merupakan sarana praktek sesuai metode uji kompetensi yaitu sebagai alat yang mensimulasikan cara kerja sistem pengoperasian peralatan permesinan diatas kapal, mendekati proses yang sebenarnya, sehingga simulator dapat digunakan untuk Test ujian komprehensif. Ujian Komprehensif memiliki pengertian ujian akhir yang bersifat menyeluruh yang diujikan berasal dari mata kuliah yang telah dipelajari selama berada di bangku perkuliahan yang bertujuan untuk menilai kompetensi mahasiswa [5].

Perlunya upaya pemerintah sebagai regulator juga dinyatakan dalam tindak lanjut keputusan Direktur Jenderal Perhubungan Laut No.HK.103/4/2/DJPL-2015, tentang sistem dan prosedur penyelenggaraan Ujian Keahlian. Dalam hal ini pemerintah perlu memberikan intervensi dalam hal penyelelnggaraan ujian keahlian, telah dikeluarkan oleh Ketua Umum Dewan Penguji 
Keahlian Pelaut (DPKP) surat DPKP/UM/230/VIII/17, berisi tentang Petunjuk Pelaksanaan Ujian Keahlian Pelaut (UKP) menggunakan Computer Base Assessment (CBA). Didalam petunjuk pelaksanaan UKP bahan materi mata uji kompetensi menggunakan CBA Test dan Praktek Komprehensif [6],[7],[8]

\section{METODE PENELITIAN}

Penelitian menggunakan metode statistik deskriptif terhadap permasalahan yang diteliti untuk dilakukannya suatu kajian mengenai Uji Komprehensif Peserta Diklat ATT -III di Politeknik Pelayaran Surabaya. Hal ini mendorong peneliti untuk melakukan upaya memberikan informasi kecukupan kebutuhan dalam menggali potensi peserta diklat di laboratorium dan simulator teknika untuk ujian komprehensif keahlian pelaut. Pengumpulan data dalam penyusunan penelitian ini dilakukan dengan mengambil data instrumen angket penilaian dari 12 dosen berlatar belakang pelaut bersertifikat ATT-I dan ATT-II. Skala penilaian bagi setiap butir instrumen yaitu dimulai dari angka 1 untuk menyatakan "Tidak tercapai”, 2 untuk "Kurang Tercapai", 3 untuk "Tercapai" dan 4 untuk "Sangat tercapai”. Instrumen yang sigunakan dalam angket Pelaksanaan Ujian Keahlian Pelaut (UKP) Test Komprehensif ATT - III disusun berdasarkan data Laboratorium dan Simulator Teknika dan berbagai literatur terkait, antara lain Pedoman pelaksanaan ujian keahlian pelaut, standart kompetensi ATT-III dalam STCW 1978 dan amandemennya. Hasil analisa dengan pendekatan statistik sesuai dengan ketentuan diperoleh data yang dibutuhkan untuk mendukung keakuratan data untuk penelitian ini.

\section{HASIL DAN PEMBAHASAN}

Hasil penelitian ini berupa gambaran kesesuaian laboratorium dan simulator teknika dalam menunjang ujian komprehensif peserta diklat ATT III di Politeknik Pelayaran Surabaya.

Dari hasil data yang di peroleh pada Fungsi 1) Permesinan kapal (marine engineering). Fungsi 2) Listrik elektronika dan sistem kontrol (electrical, electronic, control system). Fungsi 3) Perawatan dan perbaikan permesinan kapal (maintenance and repair); Fungsi 4) Pengendalian pengoperasian kapal dan perlindungan terhadap orang (controlling the operational of the ship and care for person), kondisi laboratorium dan simulator sangat dapat digunakan untuk menunjang pencapaian kompetensi ujian komprehensif Peserta Diklat ATT - III.

Laboratorium dan Simulator teknikan dan sarana penunjang lainnya digunakan sebagai fasilitas yang digunakan peserta diklat ATT-III untuk ujian komprehensif keahlian pelaut (UKP) yang dilaksakana setiap periode diklat sesuai jadwal setiap tahunnya. Adapun laboratorium dan simulator untuk menunjang tes komprehensif keahlian pelaut bagi peserta dilat ATT III ditunjuukan oleh Tabel 1, serta deskripsinya ditunjukkan melalui Tabel 2.

Tabel 1. Daftar Lab dan Simulator Teknika

\begin{tabular}{ll}
\hline No. & \multicolumn{1}{c}{ Laboratorium dan Simulator Teknika Penunjang Ujian } \\
& \multicolumn{1}{c}{ Komprehensif } \\
\hline 1. & Simulator Real Engine \\
\hline 2. & Laboratorium Listrik \\
\hline 3. & Laboratorium Sistem Kontrol \\
\hline 4. & Laboratorium Plan Logic Control (PLC) \\
\hline 5. & Laboratorium Elektronika \\
\hline 6. & Laboratorium Engine Plant \\
\hline 7. & Laboratorium Las (Welding) \\
\hline 8. & Laboratorium Bengkel Overhaul Engine \\
\hline 10. & Laboratorium Bubut (Lathe) \\
\hline
\end{tabular}


Penilaian kecukupan kompetensi, sesuai standar minimal dalam STCW 1978 dan amandemennya, ditunjukkan oleh kecukupan sarana lab dan simulator sehingga mampu mendukung ujian komprehensif keahlian pelaut (UKP), dinilai oleh ahli, dalam hal ini dosen/akademisi yang telah memiliki sertifikat Ahli Teknika Tingkat I (ATT I) serta Ahli Teknika Tingkat II (ATT I), sebagaimana ditunjukkan oleh Tabel 3

Tabel 2. Deskripsi Laboratorium, Simulator dan Workshop Teknika

\section{DESKRIPSI}

Model laboratorium dan simulator dapat mampu memperlihatkan gerakan dinamis pada sistem permesinan, termasuk dalam parameter yang penting dan interaksi diantara sistem tambahan. (The simulator models must be capable of reproducing the dynamic behaviour of the machinery systems, including the vital parameter and interactions between the secondary systems)

Model laboratorium dan simulator memperlihatkan sistem permesinan dengan prosesnya dan kontrol sistem (sensor, regulator,control, valves) yang terkoneksi dengan proses. (The simulator models must reproduce the machinery systems with their processes and control systems (sensors, regulators, controls, valves) that are connected to those processes)

Ketika mensimulasikan peralatan, gerakan/perilaku dari peralatan sebisa mungkin persis dengan perilaku aslinya. Parameter yang penting terhadap perilaku peralatan terdokumentasi. (When simulating equipment, the behaviour of the equipment must be as identical as possible to the behaviour of the real equipment. Critical parameters concerning the behaviour must be documented)

Di have be done maintenance and repair of shipboard machinery and equipment) workshop dapat dilakukan perawatan dan perbaikan permesinan dan peralatan kapal (at workshop

Di workshop dapat memiliki peralatan memadai untuk digunakan secara tepat, peralatan tenaga tangan, peralatan tenaga mesin, alat-alat ukur untuk fabrikasi dan perbaikan diatas kapal. (at workshop have be done good equipment appropriated use of hand tools and measuring instruments for fabrication and repair on board)

Model laboratorium, simulator dan workshop mampu digunkan untuk : (The laboratorium, simulator and workhop models capable use of)

1) Menjaga dinas jaga mesin tetap aman. (Maintain a safe engineering watch)

2) Menggunakan sistem komunikasi internal. (The use of internal communication systems)

3) Mengoperasikan mesin utama dan bantu dan panel kendali yang terhubung. (Operate maui and auxiliary machinery and associated control panels)

4) Mengoperasikan sistem pemompaan dan panel pengendali yang terhubung. (Operate pumping systems and associatecl control panels)

5) Mengoperasikan, kelistrikan, elektronika dan sistem control. (Operate electrical, electronic and control systems)

6) Merawat dan memperbaiki peralatan listrik dan elektronika. (Maintain and repair electrical and electronic equipment)

7) Merencanakan dan menjadwalkan operasional.(Plan and schedule operations)

8) Mengoperasikan, memonitor, dan menjaga keamanan dalam kinerja mesin utama dan permesinan bantu dan panel pengendali terhubung. (Operate, monitor, and maintain the safety and performance of the main propulsion and auxiliary machinery, and associated control panels)

9) Mengatur operasi bahan bakar dan air ballast. (Manage fuel and ballast operations)

10) Mengatur peralatan pengendali listrik dan elektronik. (Manage electrical and electronic control equipment)

11) Mendeteksi kegagalan dan kerusakan peralatan pengendali listrik dan elektronik. (Detect faults and repair electrical and electronic control equipment)

12) Memperbaiki kegagalan/kerusakan pada sistem tegangan tinggi. (Correct faults in a high-voltage system) 
13) Membuat dan mengimplementasikan sebuah prosedur untuk sistem Kelistrikan.(Create and implement a procedure for a lectrical system)

14) Menghitung ketahanan insulasi (Measure the insulation resistance)

15) Menjaga tingkat air dan tekanan uap pada boiler. (maintain water level and steam pressure) Mampu untuk mengakomodir pengujian yang khusus.

Mampu mensimulasikan pengoperasian peralatan kapal secara lebih realistis sesuai dengan kondisi sebenarnya untuk mengefektifkan pencapaian tujuan penilaian termasuk kemampuan untuk mensimulasikan kemungkinan terjadinya gangguan pada peralatan simulator.

Memiliki keadaan sebenarnya untuk memungkinkan peserta untuk menguji kemampuan sesuai tujuan pengujian

Menyediakan pengaturan keadaan sekitar, mampu untuk menciptakan berbagai keadaan, yang termasuk keadaan darurat, bahaya atau situasi yang tidak bisa sehubungan dengan tujuan pengujian

Menyediakan tampilan dimana peserta pengujian dapat berinteraksi dengan peralatan, lingkungan yang disimulasikan dan sesuai dengan instruktur

Memungkinkan seorang instruktur untuk mengatur, memonitor dan merekam pelatihan untuk debriefing peserta pelatihan yang efektif

Peralatan dan perlengkapan di laboratorium, simulator dan workhop mengakomodasi mesin-mesin dan peralatan yang biasa di temukan di kapal, mungkinkan untuk mensimulasikan beberapa komponen utama yang dibutuhkan dan tehubung pada sistem :

1. Mesin penggerak utarna dengan shaft generator;

2. Dua mesin diesel bantu (generator);

3. Pemisah minyak lumas ( lo purifier);

4. Steam boiler;

5. Pemisah bahan bakar (fo purifier);

6. Dua buah kompressor udara;

7. Sistem steering gear;

8. Pompa bahan bakar.

Simulasi mesin penggerak utama menunjukan sistem berdasarkan prinsip mesin pembakaran dalam

Peralatan dan konsol terpasang dan tersusun seperti situasi dan/atau konfigurasi pada keadaan kapal nyata

Pengendalian (control), adjusment, dan fungsi monitoring pada pengoperasian mesin utama dan permesinan bantu sistem kelistrikan, ketel, pompa, kompressor, dll juga termasuk sistem alarm

Sistem pada mesin penggerak utama mempunyai perintah (command) dan indikator status yang biasa tersedia dikapal

Sistem kelistrikan belum sepenuhnya otomatis, dimana penyediaan dan permintaan listrik dimonitor secara berkesinambungan, jika deviasi meningkat, keluar dari nilai yang ditentukan, maka sistem dapat diperbaiki, dapat memonitor frekuensi dan distribusi beban.

Laboratorium dan simulator memungkinkan untuk beroperasi dengan masukan daya listrik dari ECR atau main Switchboard, berikut pilihan-pilihan yang tersedia :

1. Remote start/ stop auxiliary diesel engines;

2. Pengoperasian shaft generator;

3. Enganging/ disenganging pada 2 generator;

4. Pemilihan otomatis dan sikuit utama;

5. Non essential users system trip;

6. Mode kestabilan frekuensi; 
7. Pemilihan macam-macam pengendalian untuk distribusi beban.

Panel distribusi utama dalam model skala penuh dengan papan distribusi yang asli, dan mempunyai kapabilitas operasional dan indikator yang biasa terdapat papan distribusi utama :

Panel distribusi utama terdiri dari :

1. Seksi dua buah generator yang terpisah;

2. Seksi sinkronisasi;

3. Seksi shaft generator;

4. Seksi memisahkan/menyambungkan emergency generator;

5. Seksi permisahan untuk macam-macam pengguna

Laboratorium dan simulator memungkinkan untuk pengoperasian pada pompa dan kompressor terdiri dari beberapa peralatan :

1. Pompa minyak lumas;

2. Pompa pendingin air tawar;

3. Pompa pendingin air laut;

4. Blower bantu;

5. Pemompaan dan sitem bahan bakar;

6. Kompressor udara;

7. Pompa steering gear;

8. Pompa ke bakaran (fire pump).

Pada ruang simulasi kamar mesin, bagian mesin yang terpenting dapat terlihat atau ditunjukan dengan cara suatu model (supaya untuk mengilustrasikan bentuk fisik)

1. Mesin penggerak utarna;

2. Mesin bantu;

3. Steam boiler;

4. Pompa bahan bakar.

Pada simulasi kamar mesin ini, satu atau lebih fasilitas operasi lokal (control panel) tersedia, dari lokal panel kontrol memungkinkan untuk mengoperasikan setidaknya beberapa mesin diantara lain :

1. Mesin utama;

2. Sistem pelumasan termasuk pelumasan minyak (purifier);

3. Sistem pendingin air tawar mesin utama;

4. Sistem pendingin air laut mesin utama;

5. Blower bantu untuk mesin utama;

6. Ketel uap;

7. Sistem bahan bakar (fo atau do), termasuk purifier;

8. Dua buah kompressor angin;

9. Sistem steering gear;

10. Sistem got;

11. Sistem ballast;

12. Pompa bahan bakar.

Di workshop dapat dilakukan membongkar dan memasang termasuk memeriksa dan kalibarasi, tersedia peralatan yang digunakan dengan tenaga tangan, peralatan tenaga mesin, alat-alat ukur untuk fabrikasi dan perbaikan diatas kapal. Di workshop tersedia juga peralatan untuk perawatan dan perbaikan permesinan dan peralatan kapal 
Tabel 3. Hasil Penilaian Kecukupan Sarana Lab dan Simulator dalam Pencapaian Kompetensi

\begin{tabular}{|c|c|c|c|c|c|}
\hline \multirow{2}{*}{ Fungsi } & \multicolumn{2}{|r|}{ Instrument Pencapaian Kompetensi } & \multirow{2}{*}{ total } & \multirow{2}{*}{$\begin{array}{l}\text { rata- } \\
\text { rata }\end{array}$} & \multirow{2}{*}{$\begin{array}{l}\text { Pencapai } \\
\text { an } \\
(\%)\end{array}$} \\
\hline & & (test oral \& praktek komprehensif) & & & \\
\hline \multirow[t]{8}{*}{1} & \multicolumn{2}{|r|}{ Oral \& praktek pada engine room simulator } & & & \\
\hline & \multicolumn{2}{|r|}{$\begin{array}{l}\text { Preparation and use of planned maintenance systems (PMS) as per } \\
\text { ISM code }\end{array}$} & & & \\
\hline & 1. & $\begin{array}{l}\text { Melaksanakan tugas jaga permesinan dengan aman (maintain a } \\
\text { safe engineering watch) }\end{array}$ & 41 & 3,42 & 85,4 \\
\hline & 2. & $\begin{array}{l}\text { Menggunakan sistem komunikasi internal (use internal } \\
\text { communication system) }\end{array}$ & 48 & 4,00 & 100,0 \\
\hline & \multicolumn{2}{|r|}{ Start up \& Shut down of main and auxiliary machines } & & & \\
\hline & 3. & $\begin{array}{l}\text { Mengoperasikan mesin induk dan mesin bantu dan sistem } \\
\text { kontrol yang terkait (operate main and auxiliary machinery and } \\
\text { associated control systems) - Pesawat Bantu }\end{array}$ & 39 & 3,25 & 81,3 \\
\hline & 4. & $\begin{array}{l}\text { Menggunakan bahasa inggris dalam bentuk tulisan dan ucapan } \\
\text { (use English in written and oral form) }\end{array}$ & 48 & 4,00 & 100,0 \\
\hline & 5. & $\begin{array}{l}\text { Mengoperasikan mesin induk dan mesin bantu dan sistem } \\
\text { kontrol yang terkait (operate main and auxiliary machinery and } \\
\text { associated control systems) - Mesin Penggerak Utama }\end{array}$ & 36 & 3,00 & 75,0 \\
\hline 1 & \multicolumn{2}{|r|}{$\begin{array}{l}\text { Operate fuel, lubricating, ballast, and others pumping systems and } \\
\text { associated control systems }\end{array}$} & & & \\
\hline \multirow[t]{4}{*}{1} & 6. & $\begin{array}{l}\text { Mengoperasikan pompa bahan bakar, pelumas, tolak bara } \\
\text { (ballast) dan sistem pompa-pompa lainnya dan sistem-sistem } \\
\text { control yang terkait. (operate fuel, lubricating, ballast, and } \\
\text { others pumping systems and associated control systems) }\end{array}$ & 48 & 4,00 & 100,0 \\
\hline & \multicolumn{2}{|r|}{$\begin{array}{l}\text { Permesinan kapal pada tingkat manajemen (marine engineering at } \\
\text { the management level) }\end{array}$} & & & \\
\hline & 7. & $\begin{array}{l}\text { Mengelola pengoperasian penataan permesinan pendorong. } \\
\text { (manage the operation of propulsion plant machinery) }\end{array}$ & 48 & 4,00 & 100,0 \\
\hline & 8. & $\begin{array}{l}\text { Pengoperasian, pegawasan, penilaian kinerja dan pemeliharaan } \\
\text { keselamatan peralatan mesin pendorong dan mesin bantu. } \\
\text { (operate, surveillance, performance assessment and } \\
\text { maintenance safety of propulsion plant and auxiliary } \\
\text { machinery) }\end{array}$ & 48 & 4,00 & 100,0 \\
\hline \multirow[t]{2}{*}{2} & \multicolumn{2}{|r|}{ oral \& praktek pada listrik, electronic \& sistem kontrol } & & & \\
\hline & \multicolumn{2}{|r|}{ Generator \& electrical distribution system } & & & \\
\hline
\end{tabular}




\begin{tabular}{|c|c|c|c|c|c|}
\hline & 9. & $\begin{array}{l}\text { Mengoperasikan sistem listrik, sistem elektronik dan sistem } \\
\text { kontrol. (operate electrical, electronic and control systems) }\end{array}$ & 48 & 4,00 & 100,0 \\
\hline & \multicolumn{2}{|r|}{ Software version control (PLC digital micro controls) } & & & \\
\hline & \multicolumn{2}{|r|}{ Calibrate \& Adjust transmitter \& controllers } & & & \\
\hline & 10 & $\begin{array}{l}\text { Perawatan dan perbaikan peralatan listrik dan electronic } \\
\text { (maintenance and repair of electrical and electronic equipment) }\end{array}$ & 40 & 3,33 & 83,3 \\
\hline & \multicolumn{2}{|r|}{$\begin{array}{l}\text { Listrik elektronika dan sistem kontrol pada tingkat manajemen } \\
\text { (electrical, electronic, control system at the management level) }\end{array}$} & & & \\
\hline & 11 & $\begin{array}{l}\text { Mengelola pengoperasian peralatan kontrol listrik dan } \\
\text { elektronika (manage operation of electrical and electronic } \\
\text { control equipments) }\end{array}$ & 48 & 4,00 & 100,0 \\
\hline & 12 & $\begin{array}{l}\text { Perawatan dan perbaikan peralatan listrik dan elektronik } \\
\text { (maintenance and repair of electrical and electronic equipment) }\end{array}$ & 48 & 4,00 & 100,0 \\
\hline \multirow[t]{7}{*}{3} & \multicolumn{2}{|r|}{ oral \& praktek pada perbengkelan } & & & \\
\hline & \multicolumn{2}{|c|}{ Dismantling and inspection/ calibrations } & & & \\
\hline & 13 & $\begin{array}{l}\text { Menggunakan secara tepat, peralatan tenaga tangan, peralatan } \\
\text { tenaga mesin, alat-alat ukur untuk fabrikasi dan perbaikan diatas } \\
\text { kapal. (appropriated use of hand tools and measuring } \\
\text { instruments for fabrication and repair on board) }\end{array}$ & 45 & 3,75 & 93,8 \\
\hline & 14 & $\begin{array}{l}\text { Perawatan dan perbaikan permesinan dan peralatan kapal } \\
\text { (maintenance and repair of shipboard machinery and } \\
\text { equipment) }\end{array}$ & 45 & 3,75 & 93,8 \\
\hline & \multicolumn{2}{|r|}{$\begin{array}{l}\text { Perawatan dan perbaikan permesinan kapal level manajemen } \\
\text { (maintenance and repair at management level) }\end{array}$} & & & \\
\hline & 15 & $\begin{array}{l}\text { Mengelola prosedur perawatan dan perbaikan secara aman dan } \\
\text { efektif (manage safe and effective maintenance and repair } \\
\text { procedures) }\end{array}$ & 48 & 4,00 & 100,0 \\
\hline & $\begin{array}{l}16 \\
.\end{array}$ & $\begin{array}{l}\text { Mendeteksi dan identifikasi penyebab tidak berfungsinya } \\
\text { permesinan dan membetulkan kegagalan (detect and identify the } \\
\text { cause of machinery malfunctions and correct faults) }\end{array}$ & 48 & 4,00 & 100,0 \\
\hline \multirow[t]{9}{*}{4} & \multicolumn{2}{|r|}{ Oral examination } & & & \\
\hline & \multicolumn{2}{|c|}{ Pollution prevention requirements } & & & \\
\hline & 17 & $\begin{array}{l}\text { Menjamin pemenuhan persyaratan pencegahan pencemaran } \\
\text { (ensure compliance with pollution preventive equipment) }\end{array}$ & 48 & 4,00 & 100,0 \\
\hline & \multicolumn{2}{|r|}{ Seaworthiness ships } & & & \\
\hline & 18 & Menjaga kelaiklautan kapal (seaworthiness ships) & 48 & 4,00 & 100,0 \\
\hline & \multicolumn{2}{|r|}{$\begin{array}{l}\text { Maritime legislative requirements (SOLAS, MLC, UU Pelayaran, } \\
\text { etc) }\end{array}$} & & & \\
\hline & 19 & $\begin{array}{l}\text { Pencegahan, pengendalian dan pemadaman kebakaran diatas } \\
\text { kapal (prevent, control and fight fires on board) }\end{array}$ & 48 & 4,00 & 100,0 \\
\hline & 20 & $\begin{array}{l}\text { Memantau sesuai dengan persyaratan - persyaratan peraturan } \\
\text { yang berlaku (monitoring compliance with legislative } \\
\text { requirement) }\end{array}$ & 48 & 4,00 & 100,0 \\
\hline & \multicolumn{2}{|r|}{ Live saving appliances } & & & \\
\hline
\end{tabular}




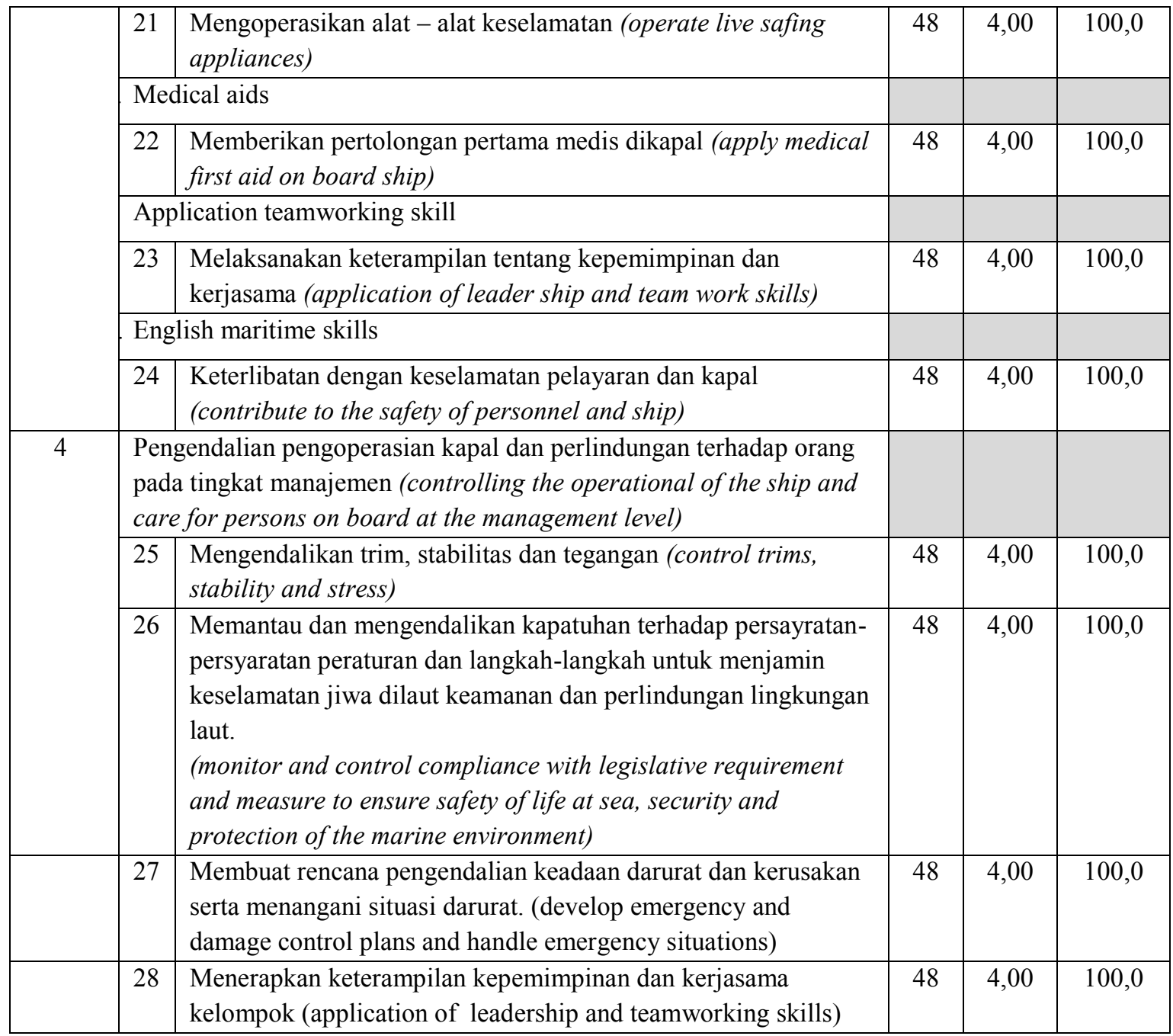

Catatan :

A. Fungsi (1)._Permesinan kapal (marine engineering); Fungsi (2). Listrik elektronika dan sistem kontrol (electrical,electronic,control system); Fungsi 3). Perawatan dan perbaikan permesinan kapal (maintenance and repair); Fungsi 4). Pengendalian pengoperasian kapal dan perlindungan terhadap orang (controlling the operational of the ship and care for person

B. Skala Penilaian 1 s.d 4 : (1) Tidak tercapai; (2) Kurang Tercapai; (3) Tercapai; (4) Sangat tercapai Grafik pada Gambar 1 sampai dengan Gambar 12 menunjukkan nilai ketercapaian laboratorium dan simulator teknika sebagaimana kompetensi yang dibutuhkan bagi peserta diklat ATT III, serta nilai maksimal pada kondisi ideal.

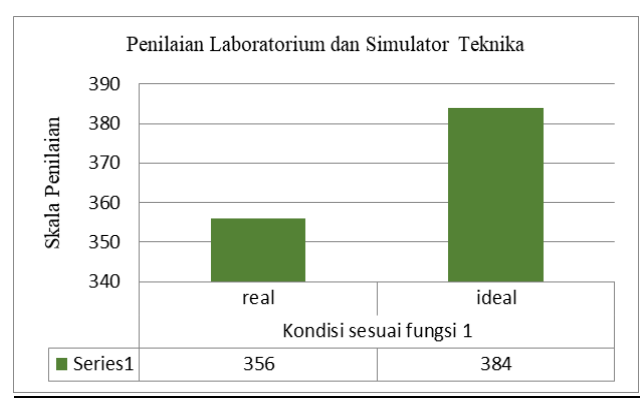

Gambar 1. Kondisi Lab dan Simulator Teknika (Fungsi 1)

Dari gambar.1 diketahui hasil penilaian untuk Fungsi 1 (8 indikator) score 356 sangat dapat digunakan. 


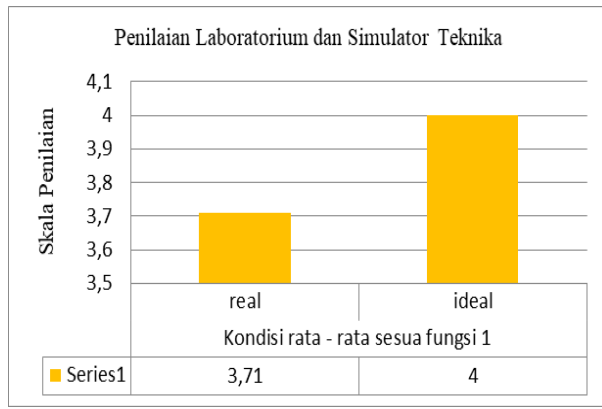

Gambar 2. Kondisi Rata-Rata Lab dan Simulator Teknika (Fungsi 1)

Dari Gambar 2. diketahui hasil penilaian untuk Fungsi 1 (8 indikator) score rata-rata 3,71 sangat dapat digunakan.

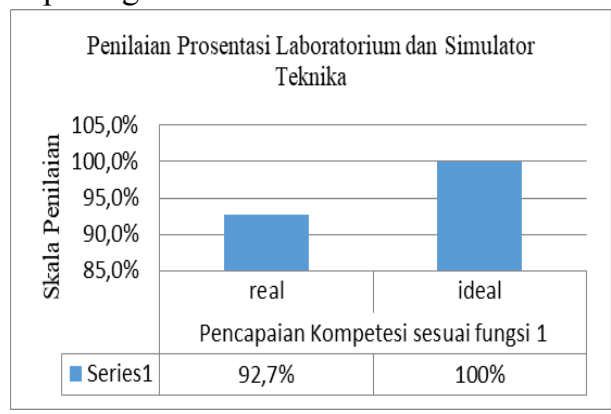

Gambar 3. Prosentase Pencapaian di Lab dan Simulator Teknika (Fungsi1)

Dari Gambar.3 diketahui hasil penilaian untuk Fungsi 1 (8 indikator) prosentasi pencapaian kompetensi $92,7 \%$ sangat dapat digunakan.

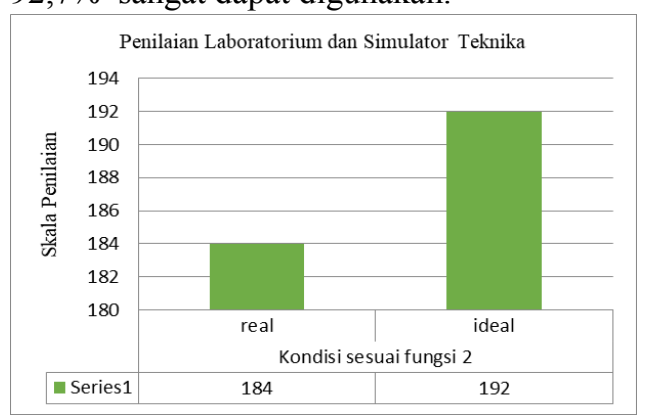

Gambar 4. Kondisi di Lab dan Simulator Teknika (Fungsi 2)

Dari Gambar 4. diketahui hasil penilaian untuk Fungsi 2 (4 indikator) score 184 sangat dapat digunakan.

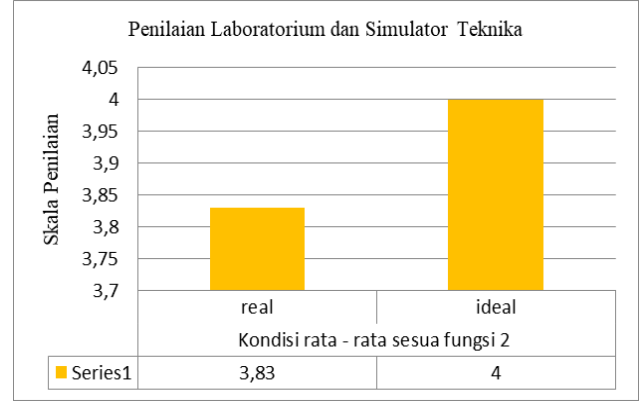

Gambar 5. Kondisi Rata-Rata Lab dan Simulator Teknika (Fungsi 2)

Dari gambar 5 diketahui hasil penilaian untuk Fungsi 2 (4 indikator) score rata-rata 3,83 sangat dapat digunakan.

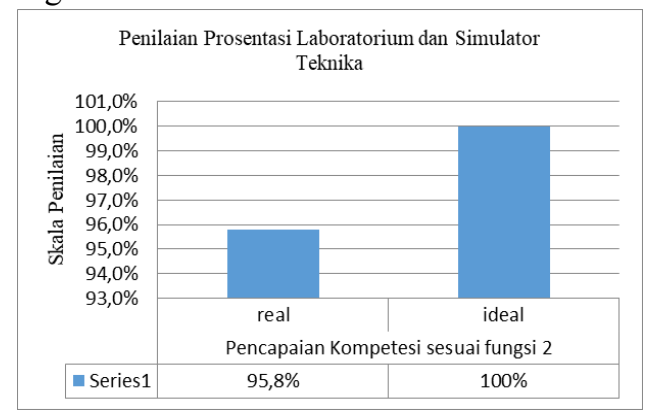

Gambar 6. Prosentase Pencapaian di Lab dan Simulator Teknika (Fungsi2)

Dari Gambar 6. diketahui hasil penilaian untuk Fungsi 2 (4 indikator) prosentasi pencapaian kompetensi $95,8 \%$ sangat dapat digunakan

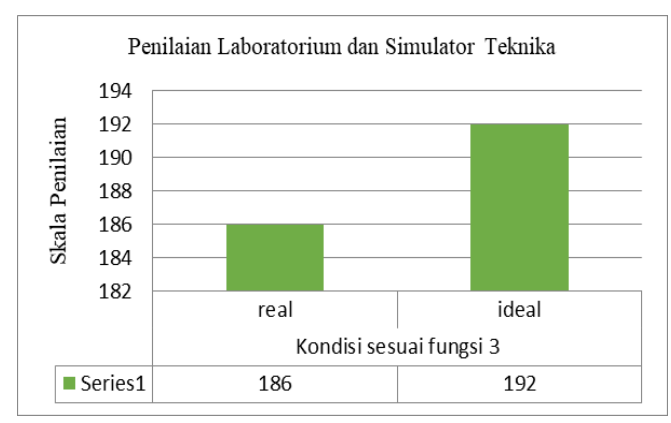

Gambar 7. Kondisi di Lab dan Simulator Teknika (Fungsi 3)

Dari gambar 7 diketahui hasil penilaian untuk Fungsi 3 (4 indikator) score 186 sangat dapat digunakan. 


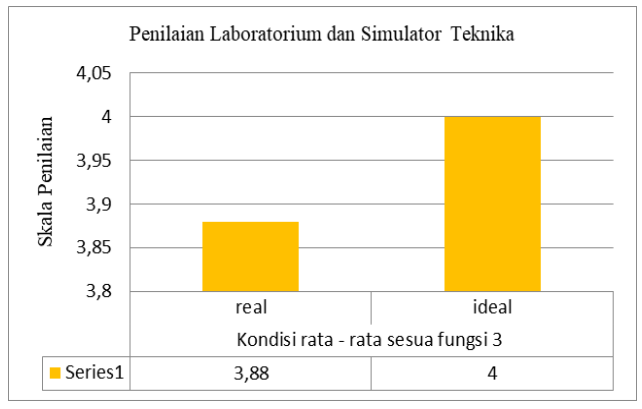

Gambar 8. Kondisi Rata - Rata di Lab dan Simulator Teknika (Fungsi 3)

Dari gambar 8 diketahui hasil penilaian untuk Fungsi 3 (4 indikator) score rata-rata 3,88 sangat dapat digunakan

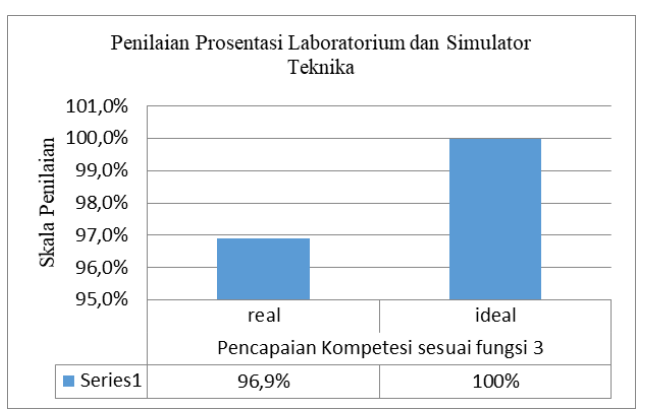

Gambar 9. Prosentase Pencapaian di Lab dan Simulator Teknika (Fungsi 3)

Dari gambar 9 diketahui hasil penilaian untuk Fungsi 3 (4 indikator) prosentasi pencapaian kompetensi 96,9\% sangat dapat digunakan.

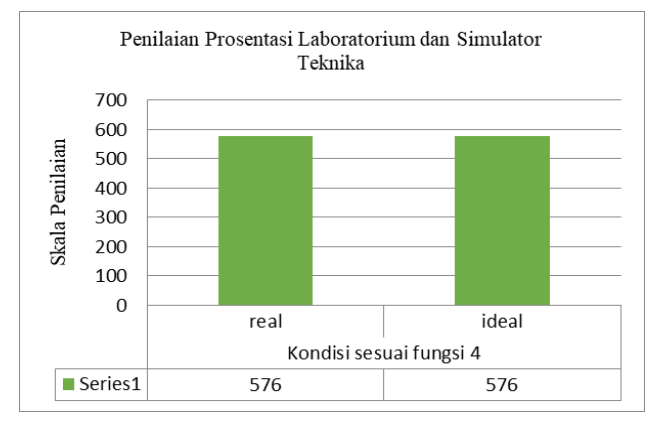

Gambar 10. Kondisi Lab dan Simulator Teknika (Fungsi 4)

Dari gambar 10 diketahui hasil penilaian untuk Fungsi 4 (12 indikator) score 567 sangat dapat digunakan.

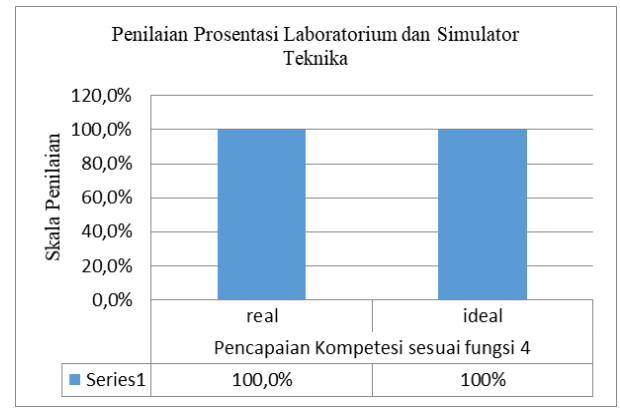

Gambar 11. Prosentase Pencapaian di Lab dan Simulator Teknika (Fungsi 4)

Dari Gambar 11. diketahui hasil penilaian untuk Fungsi 4 (12 indikator) prosentasi pencapaian kompetensi $\quad 100 \quad \% \quad$ sangat dapat digunakan.Berdasarkan hasil yang menunjukkan bahwa kondisi laboratorium dan simulator teknika sangat dapat agar dapat mengusai materi dengan baik. Bagi dosen dan peserta diklat, penguasaan pengoperasian peralatan dan berbagai gambaran kompetensi dalam skenario pembelajaran praktek menjadi sangat penting untuk mengasah kemampuan, mentransfer pengetahuan dalam bentuk kegiatan mandiri maupun diberikan tugas terstruktur. Kegiatan di waktu efektif peserta diklat dapat dimanfaatkan dengan baik melalui teori maupun praktek. Hal ini diharapkan dapat menumbuhkan

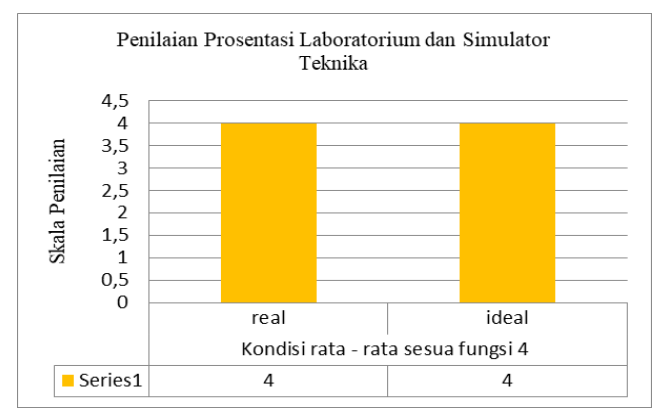

Gambar 12. Kondisi Lab dan Simulator Teknika (Fungsi 4)

Dari Gambar 11 diketahui hasil penilaian untuk Fungsi 4 (12 indikator) score rata-rata 4 sangat dapat digunakan rasa percaya diri dalam mengikuti kegiatan ujian komprehensif Ujian Keahlian Pelaut (UKP) dengan harapan dapat lulus sesuai standard minimal kompetensi dalam STCW 1978 dan amandemennya. Praktek di lab dan simulator menyita banyak waktu dan tenaga, hal ini membuat pembelajaran seakan berjalan lambat, sehingga dibutuhkan metode yang tepat dan waktu yang cukup banyak baik bagi peserta diklat maupun dosen. Pemeliharaan sarana lab dan simulator membutuhkan 
biaya dan penanganan khusus, kurangnya tenaga teknisi dan biaya perawatan menjadi hambatan besar dalam terselenggaranya pembelajaran praktek di lab dan simulator, kualifikasi dosen untuk pembelajaran praktek juga perlu ditingkatkan.digunakan untuk uji komprehensif, maka dibutuhkan sumbangsih pemikiran dan metode pembelajaran aktif, modulmodul pembelajaran, skenario praktek dan kegiatan yang membangun minat peserta diklat dalam belajar dan usaha meningkatkan kompetensi di bidang keilmuan khususnya bidang engineering. Hal tersebut menjadi tantangan bagi dosen yang terampil dan kreatif dalam meningkatkan kualitas peserta diklat sebagai upaya mengelola pembelajaran praktek di laboratorium dan simulator teknika. Kegiatan praktek dan penyesuaian peralatan harus sering dilakukan untuk menjamin kemampuan peserta diklat.

\section{KESIMPULAN}

Dari penelitian yang telah dilakukan dapat diambil kesimpulan sebagai berikut:

1. Laboratorium dan simulator teknika sangat dapat digunakan untuk uji komprehensif Ujian Keahlian Pelaut (UKP) dengan metode statistik deskiptif, analisis sarana hasilpenilaian rekapitulasi angket dengan pendekatan kuantitatif penilaian tempat uji praktek sesuai Test Komprehensif untuk Fungsi 1 berupa permesinan kapal dengan 8 indikator, memiliki score sebesar 356 dari score maksimal sebesar 384, rata-rata 3,71 dari skala 4 sehingga persentase ketercapaian tes komprehensif sebesar 92,7\%. Pada fungsi 2 berupa listrik elektronika dan sistem kontrol dengan 4 indikator, didapatkan score sebesar 184 dari score maksimal sebesar 192, rata-rata 3,83 dari skala 4 sehingga prosentase ketercapaian tes komprehensif sebesar 95,8\%. Pada fungsi 3 berupa oral \& praktek pada perawatan dan perbaikan permesinan kapal dengan 4 indikator, didapatkan score sebesar 186 dari score maksimal sebesar 192, rata-rata 3,88 dari skala 4 sehingga prosentase ketercapaian tes komprehensif 96,9\%. Untuk fungsi 4 berupa pengendalian pengoperasian kapal dan perlindungan terhadap orang dengan 12 indikator, didapatkan score 576 dari maksimal score sebesar 576, rata-rata 4 dari skala 4 , sehingga prosentase ketercapaian tes komprehensif $100 \%$.

2. Fasilitas dan perlengkapan di laboratorium dan simulator teknika dinilai sangat penting untuk hasil ujian praktek komprehensf, penyesuaian tempat ujian, peralatan dan teknologi oleh peserta diklat ATT-III Pemberian gambaran kreatifitas dalam menggali kompetensi peserta diklat di tempat uji, pengenalan tempat uji dan waktu pelaksanaan menentukan hasil uji komprehensif.

\section{Saran}

1. Laboratorium dan simulator teknika dikelola oleh tenaga - tenaga ahli dan profesional yang mampu mengoperasikan, merawat kondisi peralatan dan perlengkapan yang tersedia dan menjadi standard minimal sebagai tempat uji kompetensi.

2. Desain pembelajaran untuk pengoperasian fasilitas dan peralatan/ teknologi dibutuhkan bagi peserta diklat ATT-III sesuai standard kompetensi dalam STCW 1978 dan amandemennya, yang digunakan dalam ujian praktek komprehensf.

3. Pengenalan dan gambaran skenario praktek di laboratorium dan simulator diperlukan untuk menggali kompetensi peserta diklat dalam menyelelesaikan ujian komprehensif

\section{DAFTAR PUSTAKA}

[1] Hartanto, C.F.B.(2018). 'Pemanfaatan Simulator dalam Meningkatkan Pengetahuan dan Ketrampilan Bernavigasi Taruna Akademi Pelayaran Niaga Indonesia', Jurnal Mitra Pendidikan.Vol. 2 No. 4, hal. 404-415.

[2] Sugiono.(2012). Metodologi Penelitian Kualitatif, Kualitatif, Dan R\&D, Bandung. Alfabeta

[3] Anonim.(2011). STCW Including 2010 Manila Amandements STCW Convention and STCW Code. London: Intenational Maritime Organization.

[4] Anonim.(2014). Model Course 7.04 Officer In Charge Of an Engineering Watch . London: Intenational Maritime Organization.

[5] Aprillia.(2011). 'Bagaimanakah Penafsiran Ujian Komprehensif Menurut Civitas Akademik Universitas Trunojoyo', Jurnal Investasi.Vol. 7 No. 1 hal. 64-75.

[6] Politeknik Pelayaran Surabaya, Direktur.(2013). Keputusan Direktur Politeknik Pelayaran Surabaya Nomor : SK.599 Tahun 2013 Tentang Penetapan Kurikulum Opersional Diklat

[7] Kompetensi Kepelautan Program Diklat Pembentukan dan Peningkatan Politeknik Pelayaran Surabaya, Surabaya: POLTEKPEL 
[8] Republik Indonesia. (2012). Undang - Undang Republik Indonesia Nomor 12 Tahun 2012

Tentang Pendidikan Tinggi, Lembaran Negara Republik Indonesia Tahun 2012 Nomor 158. Jakarta: Kementerian Sekretariat Negara RI. Diambil pada 8 Pebruari 2016 pukul 14.50 wib dari: unnes.ac.id/wp-content/uploads/UUPT-12thn-2012.pdf 
Halaman ini sengaja dikosongkan 